Nebojša Gijić ${ }^{1}$

SCIENTIFIC REVIEW ARTICLE

Oliver Dimitrijević ${ }^{2}$ doi:10.5937/ekonomika1503185G

Adriana Jović - Bogdanović ${ }^{3}$ Received: May 21, 2015

Univerzizet ,, Union - Nikola Tesla“, Accepted: Jun 30, 2015

Beograd, Fakultet za poslovne studije i pravo, Beograd

\title{
CHARACTERISTICS OF JOINT INVESTMENT IN GLOBAL BUSINESS
}

\begin{abstract}
"The joint venture", which means investment, is one of the most common forms of strategic partnerships and companies, as it is shown in the stated study, is a kind of partnership that has a tendency to grow. The studies which are carried out on a large number of managers who have had past experience in joint ventures will be presented in this work. The study conducted "on - line" survey, and involved international companies, especially in the US. The work includes theoretical - technical part, which explains in detail the mode of operation of the specified category with an analysis of its application. At the end will be provided basic impressions and comments on the attached results of studies. Results of studies show that managers generally positively declare their past experience with joint ventures and expect that this partnership continues to evolve.
\end{abstract}

Key words: joint ventures, strategic alliances, mergers and acquisitions.

JEL clasification: D4, F2, F6, M1, J1

\section{КАРАКТЕРИСТИКЕ ЗАЈЕДНИЧКИХ УЛАГАЊА У ГЛОБАЛНОМ ПОСЛОВАЊУ}

\begin{abstract}
Apstrakt
„Joint venture“ y преводу заједнички подухват (улагања), један је од чешћих облика стратешких партнерстава предузећа и, као што је показано у наведеном истраживању, оваква врста партерстава показује тенденцију раста. У раду ће бити представљена истраживања која су извриена на великом броју испитаника тј. меначера који су имали у прошлости искуство у пословима заједничких улагаға. Истраживања су спроведена „он - лине“ анкетом, и обухватила су међународне компаније, посебно у САД. Рад садржи и теоријско - стручни део, у коме се детаљно објашьава начин функиионисања наведене категорије са анализом юене примене. На крају биће изнети основни утисии и коментар на приложене резултате
\end{abstract}

\footnotetext{
${ }^{1}$ nebojsa.gijic@fpsp.edu.rs

2 oliver.dimitrijevic@fpsp.edu.rs

3 adriana.jovic.bogdanovic@fpsp.edu.rs
} 
истраживања. Резултати новијих истраживања показују да се руководиоичи углавном позитивно изјашњавају о свом досадашњем искуству са заједничким улагањима и очекују да се таква партнерства даље развијају.

Кључне речи: заједничка улагања, стратешке алијансе, мериери и аквизищије.

\section{Introduction}

"Joint venture" shows common investments in which two or more persons, whether legal or natural, pool their labour and resources in order to achieve a common business, whose goal is to achieve some common business, and share profits and bear losses on flat parts, provided that the contract isn't otherwise provided. The joint venture is a special form of the contact about the partnership and it has some rules that apply to the same contract. It is significant that in this business the responsibility for the risk is equal, where every member is liable individually and unlimited for the debts that have been taken in the common investment, irrespective of the extent of their role. The subject of this work is a common business proposition or joint ventures, and in the literature can be found different definition of joint venture, because the concept can be best defined through describing certain characteristics. Often this term is defined as the merging of two or more business partners who have different areas of engagement and the types of activities in order to exchange resources, share risks and rewards of the joint venture. Joint ventures have elements of partnership, but they are typically formed for the predefined purpose and achievement of defined objectives, or specific project and therefore have a limited duration and limited in scope and purpose.

After realizing the intended business venture participants dissociate and proportionate to their share, or according to the agreement share the profits or bear the loss. In relation to this type of strategic partnership, joint venture is distinguished by pre-defined business operation that is realized in a specific time period. As a rule, the partnership includes a number of different areas with the conduct of business in more activity and aims to develop a lasting business relationship. An important item when it comes to joint ventures is actually the trust that is built, and where a joint venture has to be based. In addition, all parties must provide the resources, regardless of whether it is cash or human resources. (Stewart, 2011)

Joint ventures are often considered as a serious alternative to mergers and acquisition, and the most common partners include smaller companies and companies more or less of equal business and development capabilities, but joint ventures are possible - and between enterprises of different sizes and strengths. Managers largely express positive opinion of how joint venture was shown in the past, and even a large and powerful company accepted a joint venture with a smaller partner, only in those situations when they cannot solve the problem quickly and not solve in a way that is most convenient, for example, when they are selling a controlling stake or a complete company.

Even though the positive trend is in the implementation of joint investment, research has pointed to some inconsistencies in the management of joint ventures. 
Namely, the joint venture is managed by partners, and the structure of votes in the management of these enterprises is determined by the structure of values introduced into the joint venture. However, a lot of managers said that their companies do not have a consistent management practices in a variety of endeavours. Even companies with the most active joint ventures tend to manage their partnerships individually.

Also, a small number of respondents say that they used a standardized resource that enable consistency and the sharing of best practice and that there is a weak consensus on measuring performance of joint ventures. This is significant because the joint venture earnings from operations divided between the co-founders of the joint venture in proportion to the entered total value of the joint venture.

\section{Joint ventures in international business}

The simplest definition of joint venture is that it is a business arrangement in which two or more parties agree to combine their resources in order to achieve a certain goal. This could be a new project or any other activity. In a joint enterprise, each participant is responsible for profits, losses and expenses.

Joint ventures are defined as any long-term cooperation that is not an integration, in which two or more economic entities possess a sufficient percentage of capital ownership to the appropriate degree of control or influence on key areas of business and business decision-making. (Dunning, 1992., p. 237). As entities in the business of the joint venture may participate companies (business enterprises), public authorities, international agencies, charitable foundations and individuals. International joint ventures involve the partners originate from at least two countries.

The joint venture can be defined as a partnership of two or more companies that create a separate business entity, in the way that each participant contributions in the form of capital, technology, marketing expertise and staff, and in order to take certain economic activities. The venture is a long-term character, according to the principle: shared tax - shared risk. (Jovic, 1990).

Joint ventures can be "double-edged sword" since they can be successful or less successful, or unsuccessful, however, even though the risks are inevitable when investing are far greater benefits and profits from investments, it appears that there were strategic subjected to joint ventures and management services in an equitable manner.

Investments represent one of the main areas of macroeconomic and development policies of each country. The scope, structure and efficiency of investments undertaken in an economy basically determine the path of its development. (Stefanovic, 2008, pp 131145) The joint venture is one of several forms of foreign direct investments / investment. Direct investment is a long-term international movement of capital which is motivated by profit and in addition to the acquisition rights of ownership, control and management of the economic entity abroad. (Stojanov, 2000, p. 18) Joint ventures can be applied at home and abroad, depending on the motives of joint ventures.

International joint ventures are a form of cooperation between two or more companies from different countries, which has resulted in the establishment of a new, legally independent, business entities. (Gijić, Zdravkovic, B. Jovic, 2014, p. 129). Investors who form this new entity, are commonly named mother companies. The joint 
company is a new company which is created as a result of international joint ventures. This newly created business entity may be established (registered) in a country where they are registered parent company or in a third country. (Matic \& Ćenan, 2007, p. 17) This form of investment provides investors the right of ownership, control and management of the company to which the funds are invested with the aim of achieving a long-term economic interests. Therefore, the joint ventures represent the typical variation of investment strategy of entering and operating in the international and domestic market, and through the process of globalization, it comes to important essential role of joint ventures on a global level which application is being increased.

The basic feature of most definitions relating to foreign investments is that they prioritize the control function in business joint venture, while the second place is used for the interest of investors for the regulation of property rights in the appropriate part of the joint venture. (Sarajčić, 2011, p. 52). Numerous studies tend to show the benefits of joint ventures in order to prove the benefits of their application in the modern economy, and in the sequel we will analyse one such survey which is conducted by McKinsey \& Company. So, main hypothesis is: Joint ventures bring numerous benefits to companies, and represent one of the basic elements of the company in future operations.

\section{Strategic alliances}

Joint Ventures are a form of strategic cooperation, i.e. strategic alliances. Several major companies are linked in strategic alliances, regardless of the mutual agreement to remain independent entities. Thus, the Alliance complex business cooperation from other forms of cooperation in which, regardless of the business independence, there must be compliance objectives and goals of the whole entity and thus there are more chains "command." Independent identities and cultures of the two companies became part of the large specific cooperation in order to achieve common goals. If the alliance is achieving its objectives, there can be cross-coupling and stronger connection, so that one gets the impression that the alliance becomes one big autonomous and unique company. A specific feature of the alliance is that there are multiple centres of strategic decisionmaking. (Lei \& Slocum, 1992, pp 81-97).

Joint ventures can be created in two ways:

- $\quad$ The formation of a new plant that will produce goods or provide particular services.,

- When one partner redeems part of the capital of an existing company, i.e. with the further investment increases the sum invested in the existing economic entity.

The main difference in joint investment and integration or merger is that the common investment creates a new business entity, while the other two forms one of the company which ceases to exist. The main motives for undertaking the joint venture are: the use of complementary technologies, the provision of the necessary capital and investment funds, overcoming barriers of entry and access to international markets, the acquisition of certain market positions (Lei \& Slocum, 1992., p. 174).

Joint ventures can be both horizontal and vertical partnerships. Horizontal level often creates common management structure and the vertical level of connection is 
carried out in the context of the distribution channels. Investment items in collectively partnership may be (Mihic, 2009, p. 55):

- Production technology, know-how, patents, expertise, training, training, management,

- $\quad$ Land, equipment, local management, relations with the institutions, staff,

- Both partners invest capital, the current financial support and accountability.

Basic procedures that precede the realization of "joint venture" (JV) arrangement involves defining the following categories (Radjenovic, 2014, p. 37):

- Objectives and structures designed forms of joint venture,

- Defining production of the utility companies,

- Determination of production technologies,

- Assessing the value of equipment and other business resources,

- Estimate of the costs of technology transfer,

- Assessing and defining prices for goods and services,

- Determining the level of the required investment,

- Analysis of the market and competitors,

- The design of the volume of sales and determine distribution methods,

- Creating offers with all the details: the characteristics of products, marketing, transportation, storage, quality.,

- Marketing activities in the target market,

- The staff screening and the necessary training,

- Impact on the environment and social aspects (contribution to the community).

The mentioned activities are the subject of a feasibility study, which analyses all these factors and in the context of defined methodological answers on the questions whether the intention of the partners is justified and whether they are provided with all necessary conditions for the realization of the set goals.

In addition to the presented elements of studies that includes financial projections in a part of the total investment, the required investment, the annual return on investment, operating costs and projected income, it is necessary to define the basic conditions for the conclusion of the JV agreement. These conditions are the subject of harmonization among the partners and aim to eliminate all doubts and differences in approaches to create an acceptable agreement. After the realization it can be accessed and disassociation under defined conditions if it is in the interest of partners. JV company shall cease to exist if the JV achieve of the aims arrangements, or do not achieve, if one of the partners demands, or time out on the concluded deal. Such companies may stop operations due to the legal or financial reasons as well as changes in market conditions.

However, the business association brings with it anti-competitive (anticompetitive) risk. This risk may be of a general and permanent nature, when businesses join in the status basis, or special or shorter characters, as it is a contractual business association, such as association of business entities to participate in tenders and auctions in public procurement procedures, in the contests of the public sector in order to elect a business partner from the private sector, the award of concessions and so on. In European law of market competition shall be deemed to greater risk of negative impact on market competition, especially when there is a joint venture established by "actual or potential competitors" (Kapural, 2008, pp 64-75). 
The business association for the purpose of abuse of monopoly or dominant position on the market, or significant limitation, disruption or prevention of competition is unauthorized and shall be regulated by law and by regulations governing the protection of competition. In this way, especially treated restrictive agreements and concentrations of undertakings, including horizontal, vertical and conglomerate agreements and concentrations, including unauthorized formal and / or informal association (written grounds or concerted operation without a written basis) known as Trast, the cartels and oligopoly, which practically divides the market, some market participants are excluded from it, or they impose unfair conditions and artificially create a relationship of supply and demand, prices and other conditions and relationships in the market, which significantly prevents, restricts or distorts competition .

\section{Motives and implementation of joint investment}

The latest trends in international economic relations and business law require the entity, i.e. "Enterprise" consider and unincorporated entities, those who do not have status "persons", i.e. a legal entity in the strict juridical sense. As examples may be mentioned contractual joint ventures in EC law and in our law of foreign investment and the controlled group of business individuals in the Code of UN control of restrictive business practices. (Trifković et al, 2009, p. 94)

Joint business ventures in the international market are realized through the following six basic profiles (Sendić, 2010, p. 248):

- Research and development joint ventures.,

- Research and exploitation of natural resources,

- Engineering and investment jobs.,

- Production and manufacturing of joint ventures.,

- Buying and selling joint venture,

- $\quad$ Services of joint ventures.

Motives of joint ventures may be different, depending on whether they are common foreign investments or investments in the host country, and what use has foreign investor and what local entrepreneur.

Motives of foreign partners for joint ventures with a local partner are numerous:

- The profitability of investing their own funds or in-kind resources such as fact and law.,

- Business credit worthiness or reputation of a local partner, i.e. its material, financial, human and technical technological capabilities.,

- The security of investments and the prospects of the market in terms of commercial and non-commercial risks such as profit, secure transfer of the profit and the initial investment, the possibility of reinvesting previously invested funds, etc.

Motives of local partner in a shared venture with a foreign partner:

- $\quad$ Lack of own funds used for the purposes of modernization, expansion and construction of new facilities (manufacturing and services),

- The acquisition of new manufacturing experience, modern technology and knowledge, 
- The launch of taking their own scientific - research and innovative work,

- Development of new products,

- More efficient use of energy resources and rational use of domestic raw materials and reproductive material,

- Increasing labour productivity and product quality, and therefore the efficiency of operations,

- Expansion of exports of their own products aimed at curbing imports,

- Safe and long-term planning of the complete product range which is aimed at the domestic market and export.

The following work outlines the advantages and disadvantages tables that have investors from joint ventures.

\begin{tabular}{|c|c|}
\hline Benefits & Disadvanage \\
\hline $\begin{array}{l}\text { - Use of the benefits due to the involvement of } \\
\text { the host country., } \\
\text { - Division of IES and investment risk., } \\
\text { - The existence of property., } \\
\text { - Combining the specificity of both } \\
\text { companies., } \\
\text { - The possibility of investing in the } \\
\text { international arena with limited resources of } \\
\text { their own funds., } \\
\text { - Due to the regulations, this is the only } \\
\text { possible alternative., } \\
\text { - The local partner provides information on: } \\
\text { local market conditions, the local workforce, } \\
\text { relationships with authorities, local customers } \\
\text { and suppliers., } \\
\text { - The best ways to provide inputs or goods } \\
\text { that is difficult to obtain otherwise., } \\
\text { - To serve you giving up can be compensated } \\
\text { (by the other partner). }\end{array}$ & $\begin{array}{l}\text { - Conflicting objectives of partners } \\
\text { (individual)., } \\
\text { - Agreeing on a profit statement, income, } \\
\text { production, reinvestment price expansion., } \\
\text { - The division of profits and control of the } \\
\text { company., } \\
\text { - Takes time engagement of experts and } \\
\text { official travel (costs)., } \\
\text { - The problem of communication., } \\
\text { - The diversity of habits and business } \\
\text { practices., } \\
\text { - Problems regarding the harmonization of } \\
\text { different interests., } \\
\text { - The possibility of antitrust reactions of } \\
\text { others., } \\
\text { - Problems of determining the appropriate } \\
\text { investment and control connections. }\end{array}$ \\
\hline
\end{tabular}

Table 1. Advantages and disadvantages of joint ventures (Sendić, 2010, p. 250)

\section{Mergers and acquisitions at the global level}

A merger is a combination of the two organizations, whereby an organization ceases to exist. The acquisition represents taking control of another organization, branch organizations or other specific means of other organizations. (Popovic, Jaško, Prokić, 2010, p. 255)

In general, mergers and acquisitions of companies is the term used to denote operations which make reorganization of companies (Dimitrijevic, Gijić, B. Jovic, 2014, pp 136-138). In general terms connection is: 1. Amalgamation, merger, acquisition. 2. Download 3. Integration., Consolidate., purchase (acquisition) and so on.

M \& A represent accession of the follower into one entity under property, i.e. assuming all the rights and obligations of its predecessor. Thus, in the case where one 
person is merged with another, merged disappears, and this with whom is merged with is its general successor. Also, when two people come together, the resulting legal entity is the universal successor, i.e. an only titular set of rights and obligations.

Often the terms merger and acquisition used interchangeably, which is wrong because there are differences between these terms. Connect (merger) is a transaction in which two or more companies agree to merge into a new company, and existing companies cease to exist. On the other hand, taking (acquisitions) indicates the transaction when one company buys i.e. it is taken over by another company. Foreclosed company legally ceases to exist.

Factors that influence the company to engage in strategic alliances are varied and numerous. Limited is the following: environmental characteristics, the characteristics of the industry in which the company competes and characteristics of the organization itself. Orientation organization, its culture and the need for more efficient use of resources, stimulating effect on inclusion in the alliance (Djuricic, Janoćević, Kaličanin, 2010, p. 117). Within this group of factors are certainly the most significant changes in the needs and behaviour of consumers in the purchase process, uncertainty and risk, rapidly changing technologies, intense competition and significant changes in other elements of the environment.

Although in 2013. the volume of business has declined, the income obtained by jointing and coupling companies remained high over the long-term average (Cogman, 2014). According to analysis of McKinsey of market reactions to mergers and acquisitions of companies, net value declared VAT in 2012 with a $12.9 \%$ decrease to $12 \%$, being at the same time is still higher than the average in the same period of the last 15 years.

Although it seems that companies have higher incomes thanks to mergers and acquisitions, the truth is that they actually have less business. Perhaps, in general, the volume of mergers and acquisitions more than doubled over the last ten years, but compared to the global capital market, it is in 2013 remained at the same level - as at the end of the last cycle of mergers and acquisitions, completed 2002. and 2003. In addition, it was significantly lower than in the period from 2007.in which the activities in the field of mergers and acquisitions were at their peak. Capitalization of the global market in 2007. was $9.1 \%$, and in 2013 dropped to $7.4 \%$, which, with the exception of 2002, its lowest value since the end of the nineties. Even customers who purchase downplayed the value to acquired companies merger to shareholding society, some other companies do not do it. In the last four years, their total earnings is that great that they can hardly manage to not go into the "red".

Why do we seem that mergers and acquisitions of companies brings higher incomes? There are several possible explanations. Businesses obviously become selective and try to be the agreements concluded with greater sum of money.

In addition, it is also possible that associations which are dealing with business development and mergers and acquisitions of corporations do business more efficiently. It seems that mergers far more revenue than is the case in relation to the same period during the last economic crisis, pointing to the fact that the current situation is not a cyclical phenomenon. There is another possibility - that investors simply reward companies for reducing the amount of their balance sheet - or the share price increased low-interest loan as a result of quantitative discount. We will know only on the base on the volume of mergers and acquisitions and the further reduction of quantitative discount. 


\section{Increasing of joint ventures}

The new results showed that managers generally had a positive experience in the past when it is about joint ventures and expects the number of such partnerships to grow. Joint ventures, as well as iteration and acquisitions will increase in the coming years, under the influence of corporate partnerships which are increasing.

In the latest survey conducted by McKinsey's, $68 \%$ of respondents on this topic (Rinaudo \& Uhlaner, 2014) expected that the activity of joint ventures in their firms increase over the next five years, and 59\% of respondents expect an increase in mergers and acquisitions. Online survey was available from 11 to 21 March 2014, and has collected 1,263 responses from C - level and senior managers, representing the full scope of the region, industry, size of company, and functional specialization. 982 managers, of the total number, have had personal experience when it comes to joint ventures. In order to accommodate variations in terms of response rate, the data are measured on the basis of their contribution to the nation of subjects in the exercise of GDP at the global level.

Not surprisingly, as many companies have experience with joint ventures, greater likelihood is that they will use them. Almost $90 \%$ of respondents from companies with more than six units in operational structure, reporting that joint ventures often or occasionally are considered as a serious alternative to the acquisition and integration - compared to only $40 \%$ in companies that do not take or did not undertake date activity at all.

Moreover, the managers generally have a positive attitude about how the last collective investment are made. Most of them describe joint ventures with which they are most familiar, as a success.

Respondents also report that more than half of the joint investments of their companies meet or exceed the expectations of at least one of their mother companies (Evidence 1)

\section{Evidence 1.}

More than three-quarters of the joint ventures had achieved initial expectations or all the mother companies had benefit. $\%$ Of respondents, $1 n=982$ (Figures are summed to 100\% due to rounding). The overall effect of joint investment companies

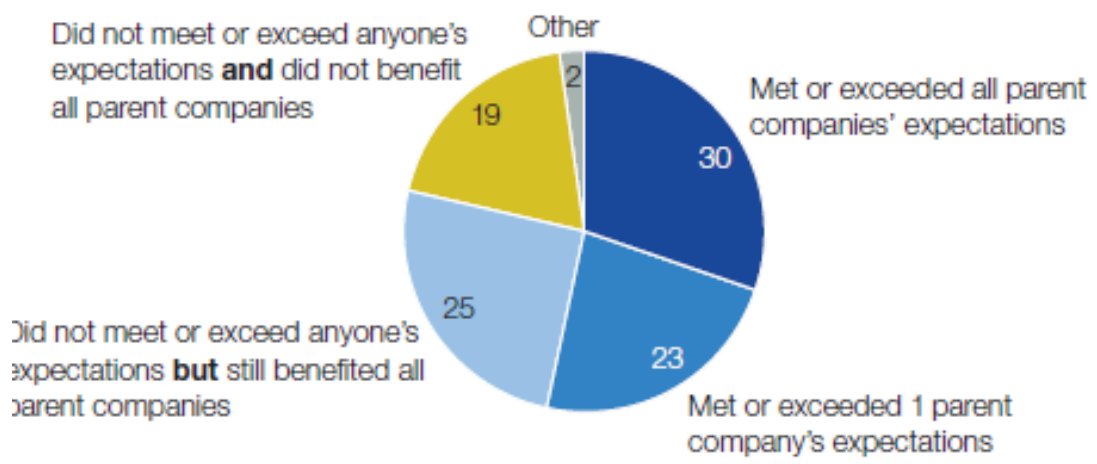


These are promising indicators for companies that currently manage joint ventures or are thinking about a new one, though, has plenty of room for improvement.

Most managers, for example, say their companies do not have a consistent management practice from one investment. In fact, even the most active companies with joint ventures tend to manage their partnerships respectively (Evidence 2).

\section{Evidence 2.}

Even companies with a large number of joint ventures tend to manage them individually, rather than as part of a portfolio of initiatives.

$\%$ of respondents. How do companies of respondents manage in the assessment of liquid of joint investments.

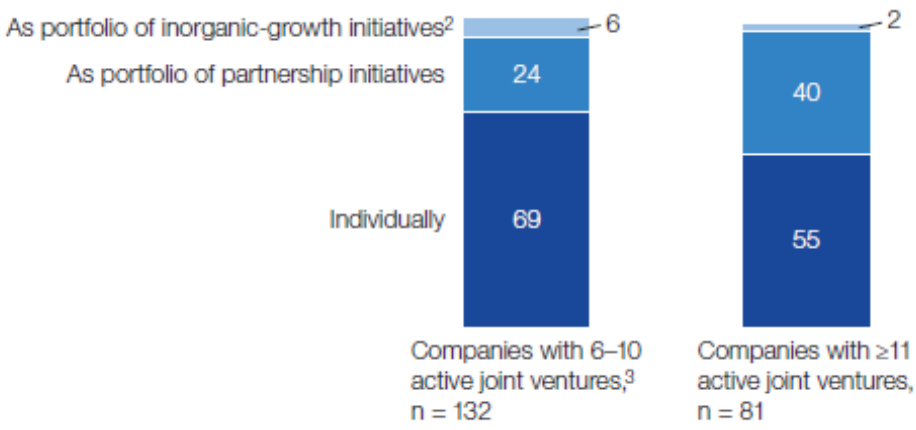

1. The figures aren't summed to $100 \%$ because the respondents gave answers like: "Other", "our joint ventures is not actively managed," or "do not know", and therefore such responses are not shown. For each category, the respondents were asked about the management of companies and at the level of the business units, segments reflect the combined responses of respondents whose companies managing joint ventures in the company and the level of the business units.

2. The portfolios of inorganic growth initiatives include the acquisition / merger and acquisitions.

3. In companies with 1 to 5 active joint ventures, executives report similar results. Considering the nature of the issues which referred to the "first active joint venture", responses cannot be set aside from the others in this group.

A small number of respondents have reported a usage of standardized resources, such as "playbooks" that enable consistency and exchange of best practice. They also have been reported a small degree of consistency in measuring the performance of joint ventures, and had different views on the interpretation of success. For example, meeting the targets revenue is widely accepted as an important measure of success, but holding the expected time frame as a milestone, it is not. 


\section{Conclusion}

Companies may have different motives in deciding and undertaking joint ventures. Depending on the expected results of joint ventures, income, respectively, profit need not be necessarily a priority, because it takes into account the different motives that were drivers of joint ventures. These motifs may relate to obtaining financial resources, technology and knowledge, as well as raw materials and equipment, managerial skills, achieve economies of scale, cost efficiency, overcome market barriers to entry, increase market share and minimize risk.

The results showed that more than three quarters of the joint ventures were fruitful and fulfilled expectations, sometimes even surpassed the same. The analysis of this research, in fact indicates the need for a joint venture, but also promote this kind of cooperation. In addition to a large number of respondents answered positively and actually sided with the joint venture as a new trend that will only come into force, even those whose companies have not had this kind of cooperation are considering joint ventures as a way of improving its business.

The only drawback on which this research suggests is the need for companies to operate individually, regardless of the large number of joint ventures. And if a joint venture can have its downside, our opinion is that the joint venture has more positive sides.

Joint venture as a form of business association may be significant for our country in terms of attracting foreign investment. Past experience shows that FDI has played an important role in the structural changes in production and exports in the beneficiary countries of these funds. For countries that have limited access to the international capital market foreign investment are "valve" for involvement of foreign funds. Thus, among the most important higher forms of economic cooperation with foreign countries are joint ventures, i.e. investments by foreign partners in local companies in order to realize the joint venture. Joint ventures are economically the most suitable form of attracting investment of the missing funds and advanced technologies, as well as the most rational and most encouraging instrument of connectivity, in the financial, technical, technological and commercial point of view, in domestic and in foreign companies.

\section{References}

Cogman, D. (2014). Global M\&A: Fewer deals, better quality, McKinsey Quarterly, June 2014, 1-3.

Dimtrijević, O., Gijić, N., Jović, B. A. (2014). Mega-mergers in the pharmaceutical industry. zbornik Aktualljnljie problemlji ekonomičeskogo razvitija 2014, vol. 1, p. p. 136-138, im. V. G. Šuhova, Belgorod.

Dunning, J. (1992). Multinational Enterprises and Global Economy. Addison Wesley Publishing Company. Boston.

Đuričin, D., Janošević, S., Kaličanin, Đ. (2010). Menadžment i strategija. Centar za izdavačku delatnost Ekonomskog fakulteta u Beogradu Beograd.

Gijić, N., Zdravković, B., \& Jović-Bogdanović, A. (2014). Veliki gradovi i svetska ekonomija. Ekonomika, 60(1), 126-139. 
Jović, M. (1990). Međunarodni kooperacioni marketing: koncept, pristup i oblici. Ekonomski fakultet u Beogradu. Beograd.

Kapural, M. (2008). Razgraničenje zajedničkog pothvata kao koncentracije i kao sporazuma u pravu tržišnog natjecanja EU. Pravo i porezi, Vol. 7, 64-75.

Lei, D., \& Slocum, J. W. (1992). Global strategy, competence-building and strategic alliances. California Management Review, 35, 81-81.

Matić, B., \& Ćenan, D. (2007). Analiza motiva za međunarodna zajednička ulaganja u Republici Hrvatskoj. Zbornik Ekonomskog fakulteta u Zagrebu, 5(1), p. p. 17 28, Ekonomski fakultet u Zagrebu, Zagreb.

Mihić, S. (2009). Menadžment u spoljnoj trgovini. Prometej. Novi Sad.

Popović, N., Jaško, O., Prokić, S. (2010). Menadžment interorganizacionih odnosa, outsourcing, strateške alijanse, merdžeri i akvizicije. Fond „Srpski ekonomski centar". Suizdavač: Institut ekonomskih nauka. Beograd.

RaRađenović, D. (2014). Strategije marketinga u cilju pripreme domaćih privrednih subjekata za strateško partnerstvo. Educons. Sremska Kamenica.

Rinaudo, K. E., Uhlaner, R. (2014). Joint ventures on the rise. McKinsey Quarterly, November 2014, 1-3.

Sarajčić, S. (2011). Analiza različitih aspekata rizika u angažovanju stranih direktnih investicija i portfolio ulaganja. DES Sarajevo. Sarajevo.

Sendić, R. (2010). Strategije ulaska na inostrana tržišta. Ekonomski fakultet u Sarajevu. Sarajevo.

Stewart, R. M. (2011). International Joint Ventures, a Practical Approach. Davis Wright Tremaine LLP. Seattle.

Stojanov, D. (2000). Međunarodne finansije u globalnoj ekonomiji. Ekonomski fakultet Sarajevo. Sarajevo.

Trifković, M., Simić, M., Trivun, V., Silajdžić, V., Mahmutćehajić, F. (2009). Međunarodno poslovno pravo. Ekonomski fakultet u Sarajevu. Sarajevo

Stefanović, M. (2008). Uticaj stranih direktnih investicija na razvoj nacionalne ekonomije. Ekonomske teme, Niš, 18(2), 131-145. 